\title{
Kuka raivaisi infoviidakkoa?
}

\author{
Sakari Kiuru (2001) \\ Seula. Valistajat ja vies- \\ tijät infoviidakossa. \\ Tilaa sivistykselle nro 3 . \\ KANSANVALISTUSSEURA
}

\section{Valistajalle ja viestijälle seula on henkinen työväline, jonka avulla hän voi palauttaa yleisölleen rahtusen mielen- rauhaa, joka takaa tilan totuu- den etsinnälle, luovuudelle ja oman järjen käytölle. Tällaista seulaa Yleisradion pääjohtajan virasta 1989 eläkkeelle jäänyt Sakari Kiuru keskustelukirjas- saan etsii.}

Kiurun uraan on kuulunut viestintäalan tehtävien lisäksi vapaan sivistystyön kausi. Niinpä hänen subjektiiviseksi mainitsemiaan ajatuksia kuuntelee arvostuksella. Kiurulla on näkemystä vanhanaikaisen hyvällä tavalla ilman kapeakatseisuuden syntiä. Keskustelukumppaneina kirjan sivuilla ovat kymmenet aikuiskasvatustieteen ja viestinnän tutkijat. Keskustelun ohessa Kiuru kuvailee valaisevasti kansansivistyksen ja aikuiskoulutuksen lähihistoriaa. Ilmiöt kytketään aikaan. Näin kirjan pääasia, eläminen infoviidakossa, ei jää irralliseksi. Kiuru vie lukijat historialliselle kävelyretkelle. Hän valaisee kehitystä alkaen autonomian ajan kansansivistyksestä ja edeten lähivuosikymmeniin ja nykyaikaan. Muutokset saavat vertailukohtia. Lukija seuraa kavalkadia mielenkiinnolla, sillä teksti rakentaa jatkuvasti linkkejä kasvatuksen maailmasta yhteiskunnallisiin tilanteisiin. Näiden rinnalle Kiuru liittää vielä oman erityistietämyksensä eli tiedonvälityksen.

\section{Kiuru kysyy: \\ "Millainen on ihmisten taito selviytyä kuiville jatkuvasti paisuvan informaatiovirran syövereistä?" Kansanvalistus- seuran Tilaa sivistykselle -sarjassa julkaistu pamfletti kohdistaa viestinsä informaatiotykityk- sen keskellä suuntaansa hapui- leville aikuiskasvattajille tai ai- kuiskouluttajille. Eikä kirjoit- taja myöskään unohda merkit- tävän oheiskasvatusinstituuti- on edustajia - siis toimittajia. Teos hakeekin yhtenä pää- juonteenaan kouluttajien ja toimittajien yhteistä toimin- taideaa informaation seulon- nassa ja välittämisessä. Lähtö- kohtana ei ensisijaisesti ole se, miten sivistystyö pärjäisi markkinoilla, vaan se, mikä olisi tavallisten ihmisten nä- kökulmasta parasta.}

\section{Vieläkö koulutus-}

markkinoiden puhetapoihin voisivat mahtua sanat valistus ja sivistys? Kansansivistysliikkeen ja vapaan sivistystyön roolina historian kulussa on Kiurun näkemyksen mukaan ollut suodattaa ja seuloa ihmisille välitettävää informaatiota. Aiemmin yhteiskunnan rakenteissa oli kautta linjan sisään kirjoitettuna tavoitteena vahvistaa kansalaisten sivistystasoa. Tämä näkyi paitsi kasvatuksen toiminnassa, säätelyssä ja valvonnassa myös viestintävälineitten osalla. Tänä päivänä voimme aiheellisesti kysyä, kuka ehtii ja kuka kokee omakseen tuon seulontatehtävän. Kilpailu ja markkinoiden ohjaavuus ovat asettaneet va- listajien joukon uuteen tilanteeseen. Kiuru kuvaa yritystään 1980-luvulla saattaa yhteen kansansivistysväkeä ja Yleisradion työntekijöitä viestintäkasvatus otsikkona. Jospa kysynnän ja tarjonnan markkinoilla olisi syntynyt kysyntää kansansivistyslinjaisesta ohjelmapolitiikasta... siis jospa. Taakseen katsoessaan Kiuru toteaa: "Ehdotuksillani ei tainnut olla sen kummempaa merkitystä."

\section{Kiuru lähtee liikkeelle} nykypäivän kuvauksesta. Elämme loputtoman informaatiotulvan tai oikeammin vyöryn ja sen yllä väijyvän infoähkyvaaran keskellä. Tiedon nimellä meille ujutetaan myös epätietoa. Käsitteellinen analyysi on paikallaan, jotta kirkastuisi se tulevaisuus, jonne haluamme mennä. Kiuru asettaa 'tietoyhteiskunta'-sanan koetteille. Korvaavia termejä voisivat olla informaatioyhteiskunta, osaamisyhteiskunta tai sivistysyhteiskunta. Tietoyhteiskuntapuheen maalailemaa näkymää voisi oikeammin nimittää tietotekniseksi yhteiskunnaksi. Vielä arveluttavampana kehityssuuntana on nähtävissä viihteellisen median hallitsema yhteiskunta. Kansalaisesta tulee kuluttaja eli kuluttaja on yhtä kuin kansalainen. Mitä silloin on kansalaisyhteiskunta?

\section{Sodanaikainen työväen-} liikkeen äänten vaientaminen tiedonvälityksessä kostautui sodan jälkeen radikalisoitumisena. Kriittisyyden teema nousi kansansivistystyössä esille. Taloudellisen kehityk- 
sen myötä suuret ikäluokat aktivoituivat muuttamaan isien kulttuuria. Naisaate, opiskelijaradikalismi ja vasemmistolaisuus nousivat julkisuuteen. Televisio aloitti ohjelmansa. Tarjonta laveni, maailma avautui ja suuntauduttiin kansainvälisyyteen. Tässä muutoksessa kansansivistäjät jäivät sivurooliin. Peräänkuulutettu kriittisyyskin oli 1970-luvulle tultaessa harvinaista.

\section{Suomi kaupungistui ja} yhteisöllisestä kulttuurista siirryttiin yksilöllisyyden korostamiseen. Vielä 1970luvulla ideaalina oli tasa-arvoisuus mahdollisuuksien tasa-arvona. Seuraavien vuosikymmenten aikana markkinavetoisessa yksilön vapautta korostavassa ilmapiirissä tasavertaisuus näyttäytyi vastustettavana tasapäistämisenä. Samalla, kun informaation määrä moninkertaistui ja jakelukanavat lisääntyivät, seulonnan asema heikkeni. Yleissivistys ei enää kiehtonut. Tärkeää oli tuottaa tehokkaita ja menestyviä pärjääjiä tietoyhteiskuntaan. Kansalaisesta tuli sopeutuja.

\section{Kiuru kysyy: \\ "Miten kansansivistysliike ja viestintävälineet toimivat kansalaisille tarpeellisen tie- don (ja viihteen) kriittisinä valikoijina, välittäjinä ja epä- tiedon torjujina, siis seulana? Miten ne opastavat nyt uus- teknologian tuottaman info- ruuhkan aikana kansalaisia va- litsemaan jyvät akanoista?" Kiurun esittämät kysymykset toimivat aikuiskasvattajan lähtökohtana. Lopullisen rat- kaisun viidakkoveistä infokas- vustossa tietään raivaavalle on vaikea antaa. Ehkä on niin,}

että on vain hellittämättä kysyttävä Kiurun tapaan: millä keinoilla infotulvasta pystyisi käytännössä seulomaan turhat pois? Miten koota ylitarjonnasta vastaanottajia parhaiten palvelevia aineksia ja näkemyksiä? Miten saada yleisö tiedostamaan omat tarpeensa? Kuinka tulvan aiheuttamia haittoja voitaisiin vähentää?

\section{Totuuden etsintä on}

ollut yhteinen juoni niin kansansivistäjillä kuin toimittajillakin. Miten kaupallistuminen vaikuttaa tähän? Kiuru on sitä mieltä, että toimittajille riittävä totuudellisuuden ohjeisto löytyy journalistin ohjeista. Vastaavaa käytäntöön sovellettua seulaa ei aikuiskasvatuksen puolelta löydy. Vapaan sivistystyön periaateteksteistä Kiuru jää kaipaamaan kriittisiä äänenpainoja. Vapaus on osittain uhrattu tuotannon ja tehokkuuden tarpeille. Infoseulan rakentamiseen antavat tarpeita akateemiset aikuiskasvatuksen tutkimukset - tosin teoreettisella tasolla, soveltamista kaivaten, toteaa Kiuru.

\section{Terve järki ja itsekuri}

ovat ne ohjenuorat, joita Kiuru seulomastaan aineistosta eväiksi tiivistää. Myös rauhoittuminen, hiljaisuus ja toimettomuus olisi nostettava kunniaan. Ne ovat kuin ruisleipää ja lähdevettä. Hyvät eväät.

\section{Mutamia vuosia sitten} eMedia-messuilla esitelmöitsijä hehkutti digitelevision autuaaksitekevänä ominaisuutena sitä, että saadaan "sohvaperuna kuluttamaan enemmän". Juuri tästä sivistyksellisestä mutakuopasta Kiuru meitä varoittaa. Hienosta PowerPoint-esityksestä oli unohtunut se mahdollisuus, että digitelevisiota voisi käyttää opiskeluun.

\section{0-luvun aikuiskasvat-} tajalla herää toisaalta Kiurun ajatuksista kysymyksiä. Millä oikeudella valistajat ja viestijät ottaisivat seulan roolin? Kuinka välttyä toisten puolesta ajattelemisen ja valitsemisen varjopuolilta? Kuka meistä tietää, mikä on totta, kaunista ja hyvää tulevaisuutta ajatellen? Kuka määrittelee sen, mikä on kansalaisten kannalta parasta? Miksi olisi oikeutettua asemoida valistettavat ja viestinnän yleisö erillisiksi muiksi, kohteiksi, seulontatyön objekteiksi? Jos viestinnän alalla heräävä kansalaisjournalismi muuttaa tätä asemointia ja kysymyksen asettelua, mikä liike kasvatuksen kentällä tekisi samaa? Sosiopedagoginen ajattelu, valtauttaminen, kriittinen pedagogiikka tai aktiiviseksi kansalaiseksi kasvattaminen voisivat kenties olla avauksia tähän suuntaan.

\section{Fyysisenä tuotteena}

Kiurun kirja on kevyt kantaa, nopea lukea ja väliotsikoineen helppo jäsentää. Liimasidoksen sivut irtoilevat ahkeralla lukijalla valitettavan nopeasti. Pientä triviaalia moitettakin on syytä antaa. Kun aihepiiri käsittelee tiedon ja epätiedon välistä seulontaa, kuulostaa ikävältä tyylirikolta se, että kirjassa nimitetään Tapio Puolimatkaa sekä Timoksi että Tuomoksi. Nykyään turhan usein saa kaihota vanhan ajan kirjapainoammattilaisia tietokoneohjelma ei korvaa asiansa osaavaa oikolukijaa vieläkään. Niin kuin ei asiansa osaavaa aikuiskasvattajaakaan.

Anne Rongas 